\title{
Draft genome sequence of Bacillus amyloliquefaciens HB-26
}

\author{
Xiao-Yan Liu' ${ }^{1}$, Yong Min ${ }^{1}$, Kai-Mei Wang ${ }^{1}$, Zhong-Yi Wan ${ }^{1}$, Zhi-Gang Zhang ${ }^{1}$, Chun-Xia \\ $\mathrm{Cao}^{1}$, Rong-Hua Zhou ${ }^{1}$, Ai-Bing Jiang ${ }^{1}$, Cui-Jun Liu ${ }^{1}$, Guang-Yang Zhang ${ }^{1}$, Xian-Liang \\ Cheng ${ }^{1}$, Wei Zhang ${ }^{2}$, Zi-Wen Yang ${ }^{1 *}$
}

\begin{abstract}
${ }^{1}$ National Biopesticide Engineering Technology Research Center, Hubei Biopesticide Engineering Research Center, Hubei Academy of Agricultural Sciences, Wuhan, China

${ }^{2}$ Department of Horticulture, Hubei Vocational College of Bio-technology, Wuhan 430070, China
\end{abstract}

*Correspondence: Zi-Wen Yang (lky666888@126.com)

Keywords: Bacillus amyloliquefaciens HB-26, next-generation sequencing, Plasmodiophora brassicae

\begin{abstract}
Bacillus amyloliquefaciens HB-26, a Gram-positive bacterium was isolated from soil in China. SDS-PAGE analysis showed this strain secreted six major protein bands of 65, 60, 55, 34, 25 and $20 \mathrm{kDa}$. A bioassay of this strain reveals that it shows specific activity against $P$. brassicae and nematode. Here we describe the features of this organism, together with the draft genome sequence and annotation. The 3,989,358 bp long genome (39 contigs) contains 4,001 protein-coding genes and 80 RNA genes.
\end{abstract}

\section{Introduction}

Bacillus amyloliquefaciens is a species of bacterium in the genus Bacillus with high affinity of $\mathrm{Ba}$ cillus subtilis. In the growth process, $B$. amyloliquefaciens can produce numerous antimicrobial or, more generally, bioactive metabolites with well-established activity in vitro such as surfactin, iturin and fengycin $[1,2]$. The production of all of these antibiotic compounds highlights $B$. amyloliquefaciens as a good candidate for the development of biocontrol agents $[3,4]$.

Strain HB-26 belongs to the species $B$. amyloliquefaciens. The type strain of the species produces much bioactive metabolites showing specific activity against Plasmodiophora brassicae which could cause Clubroot, one of the most serious diseases of brassica crops worldwide [5-7]. Heavy infection by this pathogen of Chinese cabbage, cabbage, broccoli, turnip, oilseed rape, and other crucifers can lead to severe economic losses [8-11]. The root systems of infected plants show gall formation, which inhibits nutrient and water transport, stunts plant growth, and increases susceptibility to wilting $[12,13]$. Otherwise, bioassay results showed strain HB-26 also had some rootknot nematicidal activity.
Here, we present a summary classification and a set of features for B. amyloliquefaciens HB-26, together with the description of the genomic sequencing and annotation in order to improve the understanding of the molecular basis for its ability to inhibit Plasmodiophora brassicae and nematode.

\section{Classification and features}

Strain HB-26 colonies were milky white and matte with a wrinkled surface. Microscopy observations indicated that it was a Bacillus species (Figure 1A, Figure $1 \mathrm{~B}$ and Table 1). SDS-PAGE analysis showed this strain secreted six major protein bands of 65, 60, 55, 34, 25 and $20 \mathrm{kDa}$ (Figure 1C).

A representative genomic $16 \mathrm{~S}$ rDNA sequence of strain HB-26 was searched against GenBank database using BLAST [29]. Sequences showing more than $99 \%$ sequence identity to 16 S rDNA of HB-26 were selected for phylogentic analysis, and 15 sequences were aligned with ClustalW algorithm. The tree was reconstructed by neighbor-Joining by using Kimura 2-parameter for distance calculation. The phylogenetic tree was assessed by bootstrapped for 1,000 times, and the consensus tree was shown in Figure 2. 
A

B

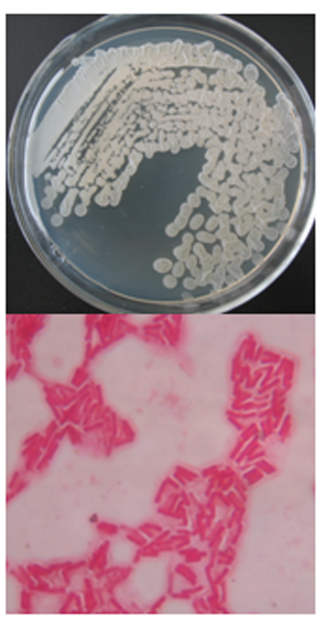

C $\quad M$

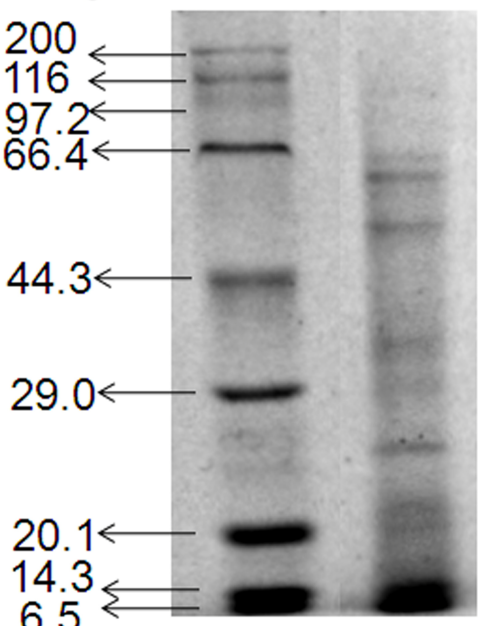

Figure 1. General characteristics of $B$. amyloliquefaciens $\mathrm{HB}-26$. (A) The colonial morphology pictures of strain HB26. (B) Phase contrast micrograph of HB-26. (C) SDSPAGE analysis of proteins of HB-26. Lane M, protein molecular weight marker; Lane 1, proteins of strain HB-26.

Table 1. Classification and general features of $B$. amyloliquefaciens HB-26

\begin{tabular}{|c|c|c|c|}
\hline MIGS ID & Property & Term & Evidence code $^{\mathrm{a}}$ \\
\hline & \multirow{7}{*}{ Current classification } & Domain Bacteria & TAS [14] \\
\hline & & Phylum Firmicutes & TAS [15-17] \\
\hline & & Class Bacilli & TAS $[18,19]$ \\
\hline & & Order Bacillales & TAS $[20,21]$ \\
\hline & & Family Bacillaceae & TAS $[20,22]$ \\
\hline & & Genus Bacillus & TAS $[20,23,24]$ \\
\hline & & Species Bacillus amyloliquefaciens & TAS [25-27] \\
\hline & Gram stain & Gram-positive & NAS \\
\hline & Cell shape & rod-shaped & IDA \\
\hline & Motility & motile & NAS \\
\hline & Sporulation & spore-forming & IDA \\
\hline & Temperature range & room temperature & NAS \\
\hline & Optimum temperature & $\mathrm{pH} 7.0$ & IDS \\
\hline & Carbon source & organic carbon source & NAS \\
\hline & Energy source & organic carbon source & NAS \\
\hline MIGS-6 & Habitat & soil & IDA \\
\hline MIGS-6.3 & Salinity & salt tolerant & NAS \\
\hline MIGS-22 & Oxygen & aerobic & NAS \\
\hline MIGS-14 & Pathogenicity & avirulent & NAS \\
\hline MIGS-4 & Geographic location & Hubei, China & IDA \\
\hline MIGS-4.1 & Latitude & $30.07 \mathrm{~N}$ & \\
\hline MIGS-4.2 & Longitude & $112.23 \mathrm{E}$ & \\
\hline MIGS-4.3 & Depth & $5-10 \mathrm{~cm}$ & \\
\hline MIGS-4.4 & Altitude & about $35 \mathrm{~m}$ & \\
\hline MIGS-5 & Sample collection time & 2009 & IDA \\
\hline
\end{tabular}

${ }^{a}$ Evidence codes - IDA: Inferred from Direct Assay; TAS: Traceable Author Statement (i.e., a direct report exists in the literature); NAS: Non-traceable Author Statement (i.e., not directly observed for the living, isolated sample, but based on a generally accepted property for the species, or anecdotal evidence). These evidence codes are from the Gene Ontology project [28] 


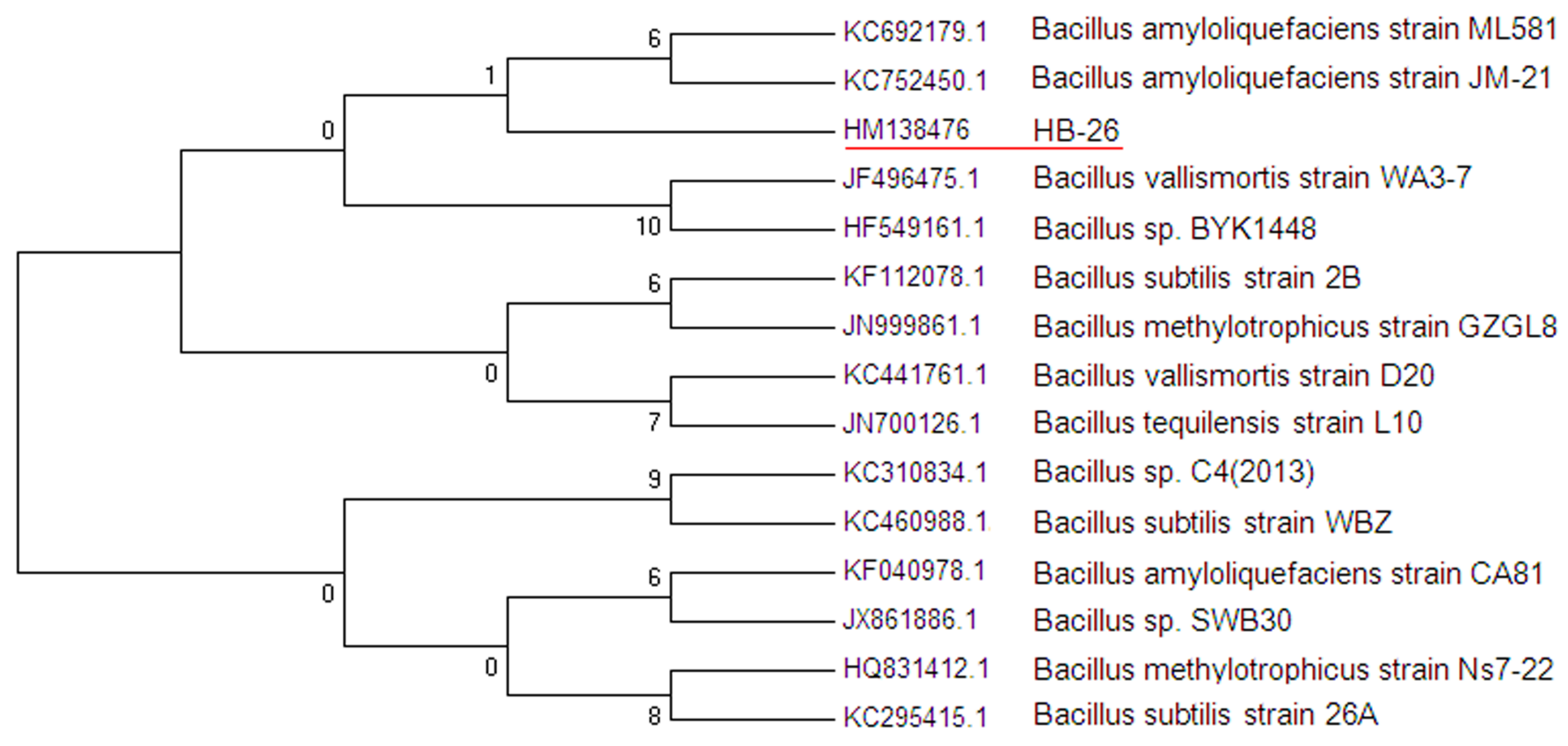

Figure 2. Neighbor-Joining Phylogenetic tree was generated using MEGA 4 based on 16S rRNA sequences. The strains and their corresponding GenBank accession numbers for $16 \mathrm{~S}$ rDNA sequences are: A: $B$. amyloliquefaciens ML581 (KC692179.1); B: B. amyloliquefaciens JM-21 (KC752450.1); C: Bacillus strain HB-26 (HM138476); D: $B$. vallismortis WA3-7 (JF496475.1); E: B. sp.BYK1448 (HF549161.1); F: B. subtilis 2B (KF112078.1); G: B.methylotrophicus GZGL8 (JN999861.1); H: B.vallismortis D20 (KC441761.1); I: B.tequilensis L10 (JN700126.1); J: B. sp. C4(2013) (KC310834.1); K: B. subtilis WBZ (KC460988.1); L: B. Amyloliquefaciens CA81 (KF040978.1) ; M: $B$. sp. SWB30 (JX861886.1) ; N: B.methylotrophicus Ns7-22 (HQ831412.1); O: B. subtilis 26A (KC295415.1). The phylogenetic tree was constructed by using the neighbor-joining method within the MEGA software [30].

\section{Genome sequencing information}

\section{Genome project history}

This Bacillus strain was selected for sequencing due to its specific activity against Plasmodiophora brassicae and nematode. The complete high quali- ty draft genome sequence is deposited in GenBank. The Beijing Genomics Institute (BGI) performed the sequencing and the NCBI staffs used the Prokaryotic Genome Annotation Pipeline (PGAAP) to complete the annotation. A summary of the project is given in Table 2 .

Table 2. Project information

\begin{tabular}{|c|c|c|}
\hline MIGS ID & Property & Term \\
\hline MIGS-31 & Finishing quality & Draft \\
\hline MIGD-28 & Libraries used & $\begin{array}{l}\text { One genomic libraries, one Illumina paired-end library (700 bp } \\
\text { inserted size) }\end{array}$ \\
\hline MIGS-29 & Sequencing platform & Illumina Hiseq 2000 \\
\hline MIGS-31.2 & Sequencing coverage & $192 \times$ \\
\hline MIGS-30 & Assemblers & SOAPdenovo 1.05 version \\
\hline \multirow[t]{4}{*}{ MIGS-32 } & Gene calling method & Glimmer and GeneMark \\
\hline & GenBank Data of Release & August 31, 2016 \\
\hline & NCBI project ID & AUWK00000000 \\
\hline & Project relevance & Agricultural \\
\hline
\end{tabular}




\section{Growth conditions and DNA isolation}

B. amyloliquefaciens HB-26 was grown in $50 \mathrm{~mL}$ Luria-Broth for $6 \mathrm{~h}$ at $28^{\circ} \mathrm{C}$. DNA was isolated by incubating the cells with lysozyme $(10 \mathrm{mg} / \mathrm{mL})$ in $2 \mathrm{~mL}$ TE $(50 \mathrm{mM}$ Tris base, $10 \mathrm{mM}$ EDTA, 20\% sucrose, pH8.0) at $4^{\circ} \mathrm{C}$ for 6 h. $4 \mathrm{~mL}$ of $2 \%$ SDS were added and the mixture was incubated at $55^{\circ} \mathrm{C}$ for $30 \mathrm{~min} ; 2 \mathrm{~mL} 5 \mathrm{M} \mathrm{NaCl}$ were added, and the mixture was incubated at $4^{\circ} \mathrm{C}$ for $10 \mathrm{~min}$. DNA was purified by organic extraction and ethanol precipitation.

\section{Genome sequencing and assembly}

The genome of $B$. amyloliquefaciens HB-26 was sequenced using Illumina Hiseq 2000 platform (with a combination of a 251-bp paired-end reads sequencing from a 700-bp genomic library). Reads with average quality scores below Q30 or more than 3 unidentified nucleotides were eliminated. 2,605,589 paired-end reads (achieving 192 fold coverage [0.94 Gb]) was de novo assembled using SOAPdenovo 1.05 version [9]. The assembly consists of 39 contigs arranged in 39 scaffolds with a total size of 3,989,358 bp (including chromosome and plasmids).

\section{Genome annotation}

Genome annotation was completed using the Prokaryotic Genomes Automatic Annotation Pipeline (PGAAP). Briefly, Protein-coding genes were predicted using a combination of GeneMark and Glimmer [31-33]. Ribosomal RNAs were predicted by sequence similarity searching using BLAST against an RNA sequence database and/or using Infernal and Rfam models [34,35]. Transfer RNAs were predicted using tRNAscan-SE [36]. In order to detect missing genes, a complete six-frame translation of the nucleotide sequence was done and predicted proteins (generated above) were masked. All predictions were then searched using BLAST against all proteins from complete microbial genomes. Annotation was based on comparison to protein clusters and on the BLAST results. Conserved domain Database and Cluster of Orthologous Group information is then added to the annotation.

Table 3. Nucleotide content and gene count levels of the genome

\begin{tabular}{lrr}
\hline Attribute & Value & \% of total \\
\hline Genome size (bp) & $3,989,358$ & 100.00 \\
DNA coding region (bp) & $3,486,615$ & 87.39 \\
DNA G+C content (bp) & $1,889,758$ & 47.37 \\
Number of scaffolds & 39 & - \\
Extrachromosomal elements & unknown & - \\
Total genes & 4,114 & 100.00 \\
tRNA genes & 76 & 1.85 \\
rRNA genes & 4 & 0.1 \\
rRNA operons & $0^{\mathrm{b}}$ & - \\
Protein-coding genes & 4,001 & 97.25 \\
Pseudo gene (Partial genes) & $0(36)$ & $0(0.87 \%)$ \\
Genes with function prediction (pro- & & \\
teins) & 2224 & $54.06 \%$ \\
Genes assigned to COGs & 2,336 & $56.78 \%$ \\
Genes with signal peptides & 328 & 7.97 \\
CRISPR repeats & 0 & 0 \\
\hline
\end{tabular}

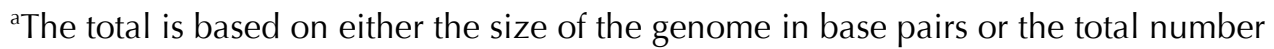
of protein coding genes in the annotated genome.

${ }^{b}$ None of the rRNA operons appears to be complete due to unresolved assembly problems. 


\section{Genome properties}

The draft assembly of the genome consists of 39 contigs in 39 scaffolds, with an overall $47.37 \%$ $\mathrm{G}+\mathrm{C}$ content. Of the 4,114 genes predicted, 4,001 were protein-coding genes, and 80 RNAs were al- so identified. The majority of the protein-coding genes (54.06\%) were assigned a putative function while the remaining ones were annotated as hypothetical proteins. The distribution of genes into COGs functional categories is presented in Table 3, Table 4 and Figure 3.

Table 4. Number of genes associated with the 25 general COG functional categories

\begin{tabular}{|c|c|c|c|}
\hline Code & Value & $\% \operatorname{age}^{a}$ & Description \\
\hline J & 130 & 3.160 & Translation, ribosomal structure and biogenesis \\
\hline A & 0 & 0.0 & RNA processing and modification \\
\hline K & 262 & 6.368 & Transcription \\
\hline $\mathrm{L}$ & 122 & 2.965 & Replication, recombination and repair \\
\hline B & 1 & 0.024 & Chromatin structure and dynamics \\
\hline $\mathrm{D}$ & 34 & 0.826 & Cell cycle control, cell division, chromosome partitioning \\
\hline Y & 0 & 0 & Nuclear structure \\
\hline $\mathrm{V}$ & 52 & 1.264 & Defense mechanisms \\
\hline $\mathrm{T}$ & 153 & 3.719 & Signal transduction mechanisms \\
\hline M & 182 & 4.424 & Cell wall/membrane/envelope biogenesis \\
\hline $\mathrm{N}$ & 53 & 1.288 & Cell motility \\
\hline Z & 0 & 0.000 & Cytoskeleton \\
\hline W & 1 & 0.024 & Extracellular structures \\
\hline$U$ & 43 & 1.045 & Intracellular trafficking, secretion, and vesicular transport \\
\hline $\mathrm{O}$ & 97 & 2.358 & Posttranslational modification, protein turnover, chaperones \\
\hline $\mathrm{C}$ & 177 & 4.302 & Energy production and conversion \\
\hline G & 249 & 6.053 & Carbohydrate transport and metabolism \\
\hline E & 340 & 8.264 & Amino acid transport and metabolism \\
\hline $\mathrm{F}$ & 79 & 1.920 & Nucleotide transport and metabolism \\
\hline $\mathrm{H}$ & 123 & 2.990 & Coenzyme transport and metabolism \\
\hline I & 117 & 2.844 & Lipid transport and metabolism \\
\hline$P$ & 205 & 4.983 & Inorganic ion transport and metabolism \\
\hline Q & 116 & 2.820 & Secondary metabolites biosynthesis, transport and catabolism \\
\hline $\mathrm{R}$ & 435 & 10.574 & General function prediction only \\
\hline \multirow[t]{2}{*}{ S } & 287 & 6.976 & Function unknown \\
\hline & 856 & 20.81 & Not in COGs \\
\hline
\end{tabular}

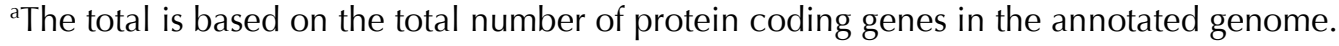




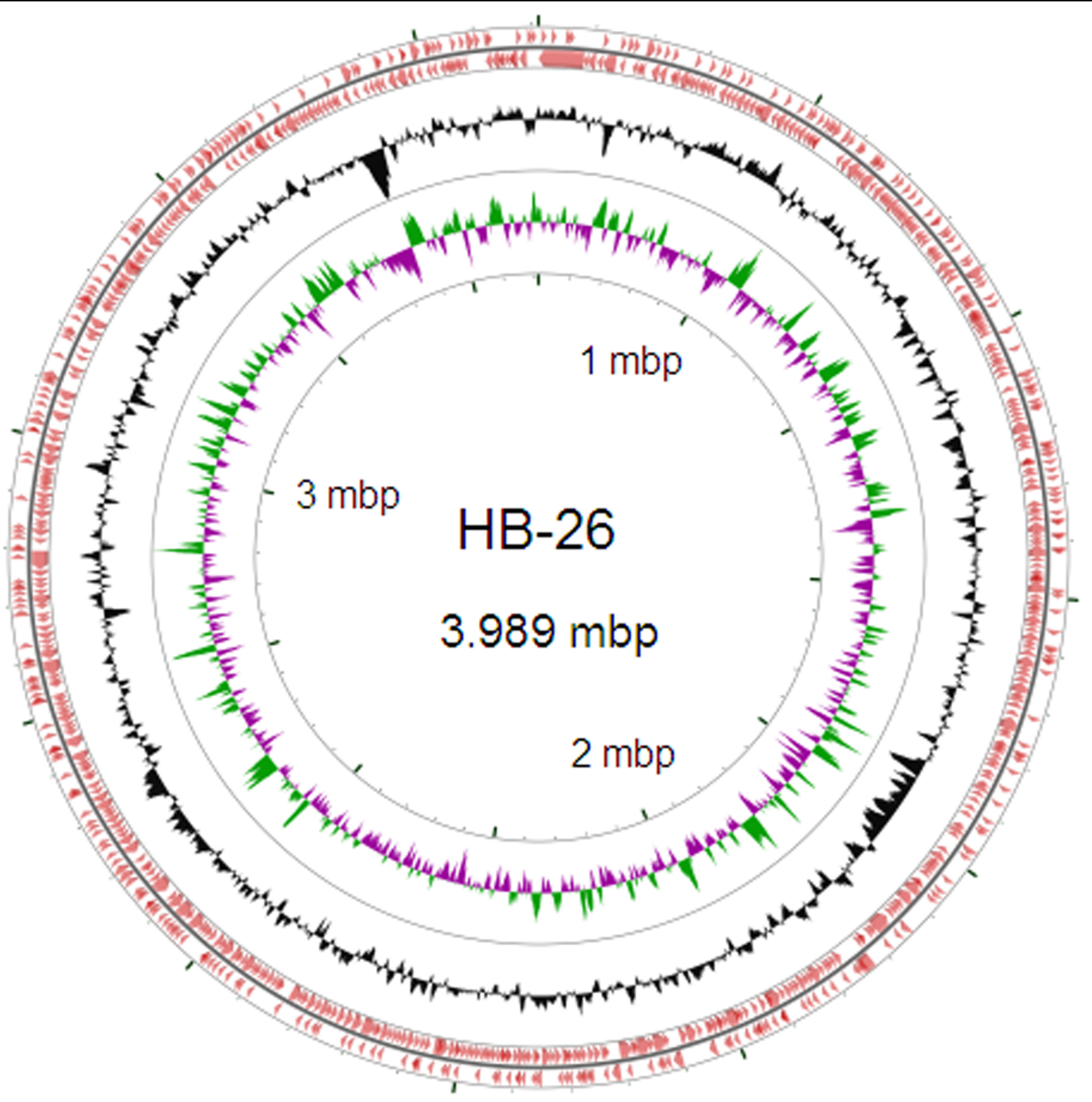

Figure 3. Graphical circular map of the Bacillus amyloliquefaciens HB-26 genome. From the outside to the center: genes on forward strand (color by COG categories), genes on reverse strand (color by COG categories), GC content, GC skew. The map was generated with the CGviewer server (Stothard Rearch Group: http://stothard.afns.ualberta.ca/cgview_server/).

\section{Acknowledgments}

This work was financially supported by the National Science and Technology Support Program (2008BADA5B03), the National 863 High Technology Research Program of China (2011AA10A201, 2011AA10A203), China 948 Program of Ministry of Agriculture (2011-G25), the National Science and Technology Support Program (2011BAB06B004-02), Hubei Province Development Plan (YJN0077) and the Science and Technology Support Program of Academy of Agricultural Sciences of Hubei Province (2012NKYJJ21).

\section{References}

1. Vilas-Bôas GT, Peruca AP, Arantes OM. Biology and taxonomy of Bacillus cereus, Bacillus anthracis, and Bacillus thuringiensis. Can J Microbiol 2007; 53:673-687. PubMed http://dx.doi.org/10.1139/W07-029

2. Chowdhury SP, Dietel K, Rändler M, Schmid M, Junge $H$, Borriss R, Hartmann A, Grosch R. Effects of Bacillus amyloliquefaciens FZB42 on Lettuce Growth and Health under Pathogen Pressure and Its Impact on the Rhizosphere Bacterial Commu- 
nity. PLOS ONE 2013; 8:e68818. PubMed http://dx.doi.org/10.1371/journal.pone.0068818

3. Helgason E, Caugant DA, Lecadet MM, Chen $\mathrm{Y}$, Mahillon J, Lovgren A, Hegna I, Kvaloy K, Kolsto AB. Genetic diversity of Bacillus cereus/B. thuringiensis isolates from natural sources. Curr Microbiol 1998; 37:80-87. PubMed http://dx.doi.org/10.1007/s002849900343

4. Arguelles-Arias A, Ongena M, Halimi B, Lara Y, Brans A, Joris B, Fickers P. Bacillus amyloliquefaciens GA1 as a source of potent antibiotics and other secondary metabolites for biocontrol of plant pathogens. Microb Cell Fact 2009; 8:63. PubMed http://dx.doi.org/10.1186/1475-2859-8-63

5. Helgason E, Okstad OA, Caugant DA, Johansen HA, Fouet A, Mock M, Hegna I, Kolsto AB. Bacillus anthracis, Bacillus cereus, and Bacillus thuringiensis--one species on the basis of genetic evidence. Appl Environ Microbiol 2000; 66:26272630. PubMed

http://dx.doi.org/10.1128/AEM.66.6.26272630.2000

6. Ticknor LO, Kolsto AB, Hill KK, Keim P, Laker MT, Tonks M, Jackson PJ. Fluorescent Amplified Fragment Length Polymorphism Analysis of Norwegian Bacillus cereus and Bacillus thuringiensis Soil Isolates. Appl Environ Microbiol 2001; 67:4863-4873. PubMed http://dx.doi.org/10.1128/AEM.67.10.48634873.2001

7. Nagaoka T, Doullah MA, Matsumoto S, Kawasaki S, Ishikawa T, Hori H, Okazaki K. Identification of QTLs that control clubroot resistance in Brassica oleracea and comparative analysis of clubroot resistance genes between $B$. rapa and $B$. oleracea. Theor Appl Genet 2010; 120:1335-1346. PubMed http://dx.doi.org/10.1007/s00122-0101259-z

8. Rocherieux J, Glory P, Giboulot A, Boury S, Barbeyron G, Thomas G, Manzanares-Dauleux MJ. Isolate-specific and broad-spectrum QTLs are involved in the control of clubroot in Brassica oleracea. Theor Appl Genet 2004; 108:15551563. PubMed http://dx.doi.org/10.1007/s00122003-1580-x

9. Chen XH, Koumoutsi A, Scholz R, Eisenreich A, Schneider K, Heinemeyer I, Morgenstern B, Voss B, Hess WR, Reva O, et al. Comparative analysis of the complete genome sequence of the plant growth-promoting bacterium Bacillus amyloliquefaciens FZB42. Nat Biotechnol 2007; 25:1007-1014. PubMed http://dx.doi.org/10.1038/nbt1325

10. Choi K, Yi Y, Lee S, Kang K, Lee E, Hong S, Young J, Park Y, Choi GJ, Kim BJ, Lim Y. Micro- organisms against Plasmodiophora brassicae. J Microbiol Biotechnol 2007; 17:873-877. PubMed

11. Helgason E, Tourasse NJ, Meisal R, Caugant DA, Kolsto AB. Multilocus sequence typing scheme for bacteria of the Bacillus cereus group. Appl Environ Microbiol 2004; 70:191-201. PubMed http://dx.doi.org/10.1128/AEM.70.1.191201.2004

12. Schnepf E, Crickmore N, Van Rie J, Lereclus D, Baum J, Feitelson J, Zeigler DR, Dean DH. Bacillus thuringiensis and its pesticidal crystal proteins. Microbiol Mol Biol Rev 1998; 62:775-806. PubMed

13. Ashburner M, Ball CA, Blake JA, Botstein D, Butler $\mathrm{H}$, Cherry JM, Davis AP, Dolinski K, Dwight SS, Eppig JT, et al. Gene ontology: tool for the unification of biology. The Gene Ontology Consortium. Nat Genet 2000; 25:25-29. PubMed http://dx.doi.org/10.1038/75556

14. Woese CR, Kandler O, Wheelis ML. Towards a natural system of organisms: proposal for the domains Archaea, Bacteria, and Eucarya. Proc Natl Acad Sci USA 1990; 87:4576-4579. PubMed http://dx.doi.org/10.1073/pnas.87.12.4576

15. Gibbons NE, Murray RGE. Proposals Concerning the Higher Taxa of Bacteria. Int / Syst Bacteriol 1978; 28:1-6.

http://dx.doi.org/10.1099/00207713-28-1-1

16. Garrity GM, Holt JG. The Road Map to the Manual. In: Garrity GM, Boone DR, Castenholz RW (eds), Bergey's Manual of Systematic Bacteriology, Second Edition, Volume 1, Springer, New York, 2001, p. 119-169.

17. Murray RGE. The Higher Taxa, or, a Place for Everything...? In: Holt JG (ed), Bergey's Manual of Systematic Bacteriology, First Edition, Volume 1, The Williams and Wilkins Co., Baltimore, 1984, p. 31-34.

18. List of new names and new combinations previously effectively, but not validly, published. List no. 132. Int I Syst Evol Microbiol 2010; 60:469472. http://dx.doi.org/10.1099/ijs.0.022855-0

19. Ludwig W, Schleifer KH, Whitman WB. Class I. Bacilli class nov. In: De Vos P, Garrity G, Jones D, Krieg NR, Ludwig W, Rainey FA, Schleifer KH, Whitman WB (eds), Bergey's Manual of Systematic Bacteriology, Second Edition, Volume 3, Springer-Verlag, New York, 2009, p. 19-20.

20. Skerman VBD, McGowan V, Sneath PHA. Approved Lists of Bacterial Names. Int I Syst Bacteriol 1980; 30:225-420. http://dx.doi.org/10.1099/00207713-30-1-225

21. Prévot AR. In: Hauderoy P, Ehringer G, Guillot G, Magrou. J., Prévot AR, Rosset D, Urbain A (eds), 
Dictionnaire des Bactéries Pathogènes, Second Edition, Masson et Cie, Paris, 1953, p. 1-692.

22. Fischer A. Untersuchungen über bakterien. Jahrbücher für Wissenschaftliche Botanik 1895; 27:1-163.

23. Cohn F. Untersuchungen über Bakterien. Beitr Biol Pflanz 1872; 1:127-224.

24. Gibson T, Gordon RE. Genus I. Bacillus Cohn 1872, 174; Nom. gen. cons. Nomencl. Comm. Intern. Soc. Microbiol. 1937, 28; Opin. A. Jud. Comm. 1955, 39. In: Buchanan RE, Gibbons NE (eds), Bergey's Manual of Determinative Bacteriology, Eighth Edition, The Williams and Wilkins Co., Baltimore, 1974, p. 529-550.

25. Priest FG, Goodfellow M, Shute LA, Berkeley RCW. Bacillus amyloliquefaciens sp. nov., nom. rev. Int J Syst Bacteriol 1987; 37:69-71. http://dx.doi.org/10.1099/00207713-37-1-69

26. Wang LT, Lee FL, Tai CJ, Kuo HP.Bacillus velezensis is a later heterotypic synonym of Bacillus amyloliquefaciens. Int I Syst Evol Microbiol 2008; 58:671-675. PubMed http://dx.doi.org/10.1099/ijs.0.65191-0

27. Fukomoto J. Studies on the production of bacterial amylase. I. Isolation of bacteria secreting potent amylase and their distribution. Nippon Nogeikagaku Kaishi 1943; 19:487-503. http://dx.doi.org/10.1271/nogeikagaku1924.19.7 487

28. Altschul SF, Gish W, Miller W, Myers EW, Lipman DJ. Basic local alignment search tool. J Mol Biol 1990; 215:403-410. PubMed

29. Li R, Zhu H, Ruan J, Qian W, Fang X, Shi Z, Li Y, Li S, Shan G, Kristiansen K, et al. De novo assembly of human genomes with massively parallel short read sequencing. Genome Res 2010;
20:265-272. PubMed

http://dx.doi.org/10.1101/gr.097261.109

30. Tamura K, Peterson D, Peterson N, Stecher G, Nei M, Kumar S. MEGA5: molecular evolutionary genetics analysis using maximum likelihood, evolutionary distance, and maximum parsimony methods. Mol Biol Evol 2011; 28:2731-2739. $\underline{\text { PubMed }}$ http://dx.doi.org/10.1093/molbev/msr121

31. Besemer J, Lomsadze A, Borodovsky M.

GeneMarkS: a self-training method for prediction of gene starts in microbial genomes. Implications for finding sequence motifs in regulatory regions. Nucleic Acids Res 2001; 29:2607-2618. PubMed http://dx.doi.org/10.1093/nar/29.12.2607

32. Delcher AL, Harmon D, Kasif S, White O, Salzberg SL. Improved microbial gene identification with GLIMMER. Nucleic Acids Res 1999; 27:4636-4641. PubMed http://dx.doi.org/10.1093/nar/27.23.4636

33. Lukashin AV, Borodovsky M. GeneMark.hmm: new solutions for gene finding. Nucleic Acids Res 1998; 26:1107-1115. PubMed http://dx.doi.org/10.1093/nar/26.4.1107

34. Griffiths-Jones S, Bateman A, Marshall M, Khanna A, Eddy SR. Rfam: an RNA family database. Nucleic Acids Res 2003; 31:439-441. PubMed http://dx.doi.org/10.1093/nar/gkg006

35. Eddy SR. A memory-efficient dynamic programming algorithm for optimal alignment of a sequence to an RNA secondary structure. BMC Bioinformatics 2002; 3:18. PubMed http://dx.doi.org/10.1186/1471-2105-3-18

36. Lowe TM, Eddy SR. tRNAscan-SE: a program for improved detection of transfer RNA genes in genomic sequence. Nucleic Acids Res 1997; 25:955-964. PubMed http://dx.doi.org/10.1093/nar/25.5.0955 